\title{
Development of Occupational Health in Japan
}

\author{
Kenzaburo TsUCHIYA \\ President, University of Occupational and Environmental Health, Japan. Kitakyushu 807, Japan
}

Abstract: This paper was presented as a Lucas Lecture 1990 before the Faculty of Occupational Medicine, Royal College of Physicians, United Kingdom. It describes the development of occupational health in Japan including primitive industrialization (mining, smelting and others) back as far as the 8th century. The modern industrialization of Japan began slightly over one hundred years ago, i. e. from the beginning to the middle of the Meiji era. Before World War II, Japanese workers in industry suffered terrible working conditions, represented by a booklet published in 1925 entitled "The Tragic History of Female Workers" by Wakizo Hosoi. At that time a pioneer named Dr. Gito Teruoka was hard at work. He literally became the "Father of Occupational Health" in Japan. He established the Kurashiki Institute of Science of Labour in 1921 in Kurashiki City located in western Honshu, which is the main island of Japan. At the beginning of the Showa era, from 1930 to 1950, various types of occupational diseases were reported and the situation was overviewed by Dr. Juko Kubota. The rapid industrialization immediately after World War II during which workers were exposed to chromium, benzidine, $\beta 2$-naphthylamine, arsenic, vinyl chloride monomer, asbestos, bischloromethyl ether and other chemicals gave rise to occupational cancer. The Ministry of Labour (MOL) was established in 1947 and the Labour Standard Law enacted. As a result, the incidence of tuberculosis decreased rapidly and occupational health emphasized the early detection of tuberculosis. After tuberculosis was nearly eradicated, more complicated working conditions developed in various industries. MOL enacted the Industrial Safety and Health Law in 1972 and occupational health practices improved greatly. Furthermore, in 1988 MOL amended the Law and announced guidelines on maintenance and promotion of health for the work population. However, there is a great disparity in occupational health services between large establishments and small factories. The University of Occupational and Environmental Health, Japan, (UOEH) was established in 1978 to promote occupational health sciences as well as to train and foster occupational health personnel to meet the short supply of occupational health physicians. However, there is no authority that establishes standards for occupational health physicians and nurses. The urgent necessity of establishing an authorized institution for the qualification of occupational health personnel is emphasized.

Key words: history of occupational health in Japan, Juko Kubota, Gito Teruoka, industrial health and safety in Japan, University of Occupational and Environmental Health, Japan.

\section{Preface}

Occupational health is defined as the social application or art of occupational health science, similar to the concept which Winslow presented with regard to public health. The practice of occupational health as an art differs from nation to nation, and can differ even in various communities within the same nation. The background of the development 


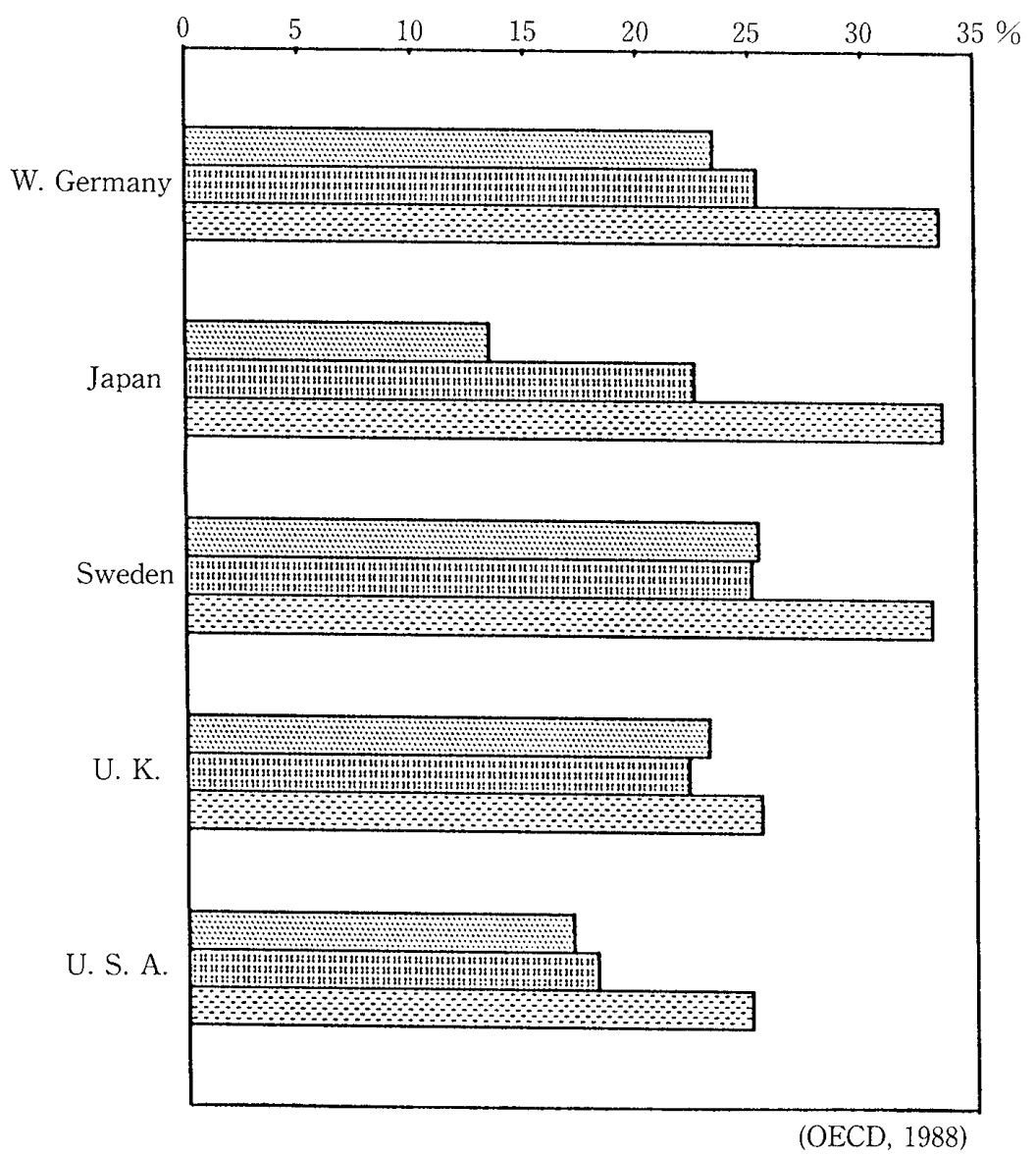

Fig. 1. Index of the aged population.

$$
\begin{gathered}
\left(\frac{\text { aged population }(65 \text { years and over })}{\text { productive age population }(15-\text { under } 65 \text { years })} \times 100\right) \\
\text { Year }: \text { 1980, } 2020
\end{gathered}
$$

of occupational health thus depends on the culture, history (particularly of industrialization), concepts, religion, socio-economic conditions, political or administrative structure and so forth.

Since it is impossible to introduce the entire social background of Japan in this short presentation, only those major events which are important in my personal view will be summarized here.

Japan has a long history; more than 2600 years have passed since the first emperor appeared on the scene. Until quite recently, agriculture was the primary occupation of the Japanese people. Now, however, the farming population makes up only $7 \%$ of the total work population of approximately 60 million and many farmers often have other part-time jobs, mostly in industry, including the service industry.

In addition to the rapidly changing industrial structure, the Japanese population has been aging so fast (Fig. 1) that individuals 65 years and over are expected to comprise $22.6 \%$ (about the same as in the United Kingdom) of the productive age population by the 


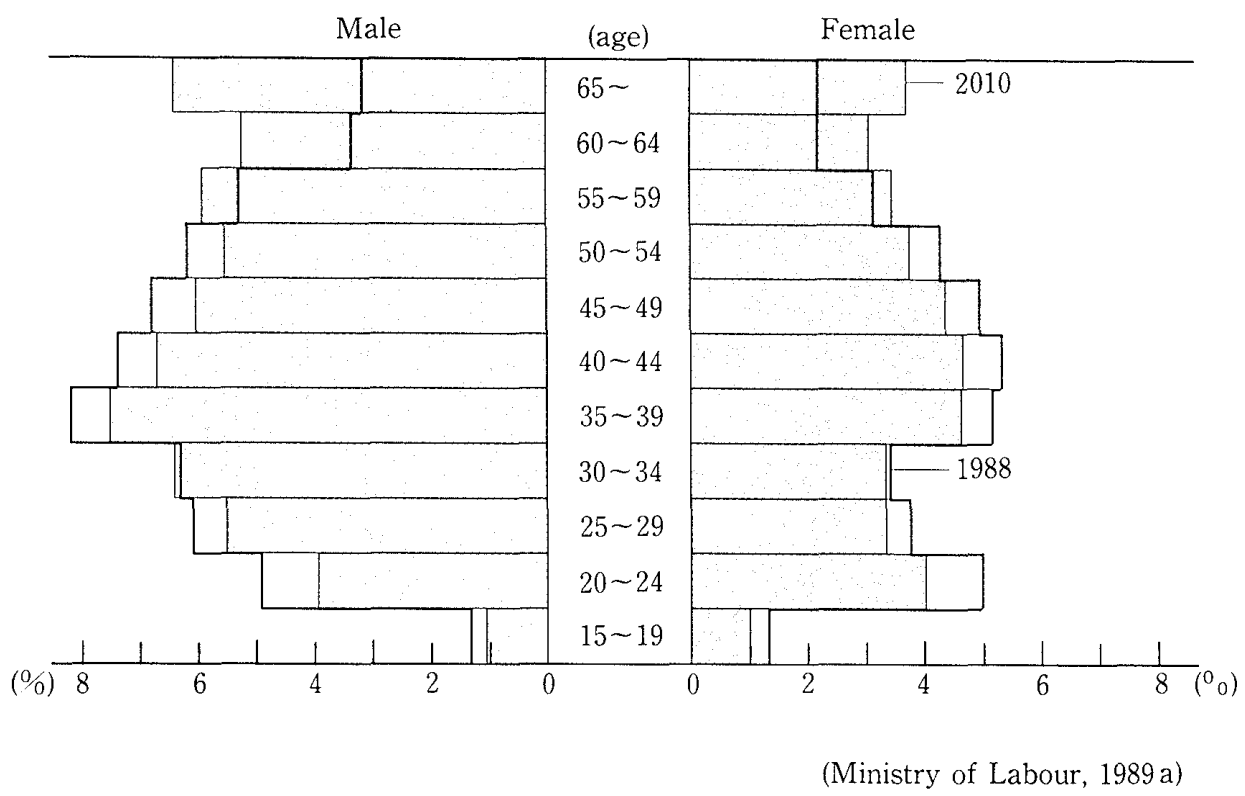

Fig. 2. Work population structure.

beginning of the 21st century, (Organization for Economic Co-operation and Development, 1988). This means that the elderly work population has been increasing very fast in recent years, as shown in Fig. 2 (Ministry of Labour, 1989a). In contrast, the young work population has been decreasing.

Thus, the basic feature of industrialization and the structure of the work population are changing rapidly, and occupational health must cope with such transformations.

\section{History of Industrialization and Occupational Health in Japan}

The history of industrialization and occupational health is described in detail by Miura (1978, 1980a, b, 1981) in Japanese. Another volume, also in Japanese, contains historical pictures of the mining, smelting and other industries as well as occupational diseases. This was edited by Kubota and entitled Atlas of Occupational Diseases (1979). Recently, my paper "A Brief Overview of Occupational Health in Recent Japan" was published in the Journal of Occupational Medicine, Singapore (Tsuchiya, 1990). In this paper I quote parts of Miura's book, some of which I will also introduce here.

There also exists a booklet which describes mining and the health conditions of gold miners in 15th century Japan. The miserable conditions to which miners were exposed as described in De Re Metallica by Agricola in 1556 and by Masumi Sugae in 1803 (Miura, 1976) indicate startling similarities. Miura notes in his book, "according to Sugae in 1803, 'the miners of Ookuzu Gold Mine died very young; few lived beyond forty years of age. Accordingly, many wives of those workers in this mine were forced to re-marry 7 to 8 times in their lifetime." Agricola states, "if the dust has corrosive qualities, it eats away the lungs, and implants consumption in the body; hence in the mines of the Carpathian 
Mountains, women are found who have married seven husbands, all of whom this terrible consumption has carried off to a premature death" (Hoover \& Hoover, 1950). It is surprising that the number of husbands for one wife is the same in both cases.

In 745 a large gold-plated Buddha was constructed in Nara, Japan. This is now a national treasure and world famous statue. Miura mentions that the statue was plated with an amalgam of gold and mercury, then set afire to get rid of the mercury. It is assumed that many workers were poisoned by the mercury vapor and some no doubt died of it.

There are many other stories; these are just a few examples of what happened in old Japan.

Japanese people worked in other primitive industries. A painting by Kano around 1600 shows a blacksmith. In the left corner of the picture is a cage in which a small bird is kept. The bird is not for the workers' enjoyment, but it is assumed that they knew that the bird was very sensitive to carbon monoxide and used it as an indicator for detecting excessive CO. Another picture by an anonymous artist shows the terrible working conditions of a gold mine in Sado. Occupational health protection in the smelting industry was very limited and the workers had to protect themselves from the heat from silver smelting by wearing special masks made from weeds and other plants. An illustration from the beginning of the textile industry which was first inaugurated in 1872 shows a Westerner, who is a French gentleman, teaching young Japanese female workers how to operate the machines. The girls in Japanese kimono in this picture look pretty and healthy. According to Miura (1978, 1980a, b, 1981), in the beginning of industrialization it was difficult to recruit female workers and girls from fairly wealthy families were employed. These families sent their girls to work because aiding the development of the Japanese nation was a mark of loyalty to the government. However, the treatment of female workers by the textile industry became very bad, as will be discussed further on. A picture believed to have been taken at the end of the 19th century shows female coal miners, but mine work by females was socially criticized and prohibited by law in 1933.

Modern industrialization in Japan began slightly over one hundred years ago, i. e. from the beginning to the middle of the Meiji era. Various publications describe the working conditions in industry and agriculture as rapidly developed primitive capitalism. By the end of the Meiji era, in 1909, the Factory Law regulating wages, working hours, child protection, etc. was submitted to the Diet of Japan, but it took several years for it to pass. However, actual working conditions remained very bad. A book published in 1925 entitled The Tragic History of Female Workers by Wakizo Hosoi (a male worker), describes in detail the working hours, wages, nutritional and sanitary conditions of dormitories and so forth of young female workers in the textile industry. Lured by propaganda, young female workers left poor farms in rural areas for the cities to be employed by industry. Working, living and nutritional conditions were so bad that many of them came down with tuberculosis. The female workers suffering from this disease were forced to return to their 
homes where they became the source of its spread throughout the rural areas of Japan.

In the midst of such bitter experiences, there lived a pioneer named Dr. Gito Teruoka, known as the "Father of Occupational Health" in Japan. In 1921 he established the Kurashiki Institute of Science of Labour under the sponsorship of Magosaburo Ohara, who had a textile business in Kurashiki. Teruoka, with the great understanding of Ohara, made efforts to improve, first of all, the general working conditions of employees. Although he was able to improve working conditions to some extent, the Japanese economy was slowing down and the military began to control Japanese society in numerous ways.

Kubota, who, you may recall, compiled the Atlas of Occupational Diseases, reported many typical occupational diseases, including pneumoconiosis, particularly due to toxic chemicals at the beginning of the Showa era; that is, about 60 to 70 years ago. However, for some years before and during World War II , there are no reliable statistics available. In addition to the atlas, Kubota reported many typical occupational diseases due to toxic chemicals such as lead, mercury, carbon disulphide and also silicosis, at the beginning of the Showa era, from 1930 to about 1950. The atlas edited by Kubota showed many cases of pneumoconiosis with pictures of X-ray film or large lung sections, but most of the compensated occupational diseases in Japan in terms of number were cases of dermatitis. Chronic dermatitis caused by formaldehyde was discovered by Kifuji. A case of dermatitis caused by tetraethylenetriamine mixed with other chemicals used as a hardener of epoxy resin was reported by Ishizu in 1964. There are cases of facial acne-like dermatitis, not occupational in origin but caused by the ingestion of rice oil contaminated with PGB. Numerous other occupational skin diseases are also noted in the atlas edited by Kubota. A case of lead poisoning in which I played a role is also introduced in the atlas. About twenty years ago a man with extremely dropped wrists came to see me. Another physician had misdiagnosed him as suffering from diabetic polyneuritis, but fortunately I was immediately able to tell that he was really suffering from lead poisoning.

The work environment in Japan has improved since 1960-1965 and few chronic (clinical) occupational diseases have been reported in recent years. However, the rapid industrialization immediately after World War II, during which workers were exposed to chromium, arsenic, vinyl chloride monomer, asbestos, or bischloromethyl ether, has given rise to occupational cancer.

In 1947, the Japanese goverment established the Ministry of Labour (MOL) and the Labour Standard Law (LSL) was enacted. According to this law, employers were obliged to have periodic and other health (medical) examinations performed on workers by physicians. Tuberculosis was so widely prevalent in 1947 that the main purpose of the periodic medical examination was to discover cases of tuberculosis at an early stage and to treat the disease. Indirect X-ray photographs became available, and treatment by artificial or surgical pneumothorax including antibiotics administration was introduced. Nutritional conditions and the general standard of living of the Japanese also improved considerably. As a result, the mortality and morbidity of tuberculosis went down so 
sharply that some called it a miracle. Around 1955, laws for the prevention of pneumoconiosis, lead poisoning and other occupational diseases were added to the LSL. However, by the time Japan reached the peak of industrialization, neither employers nor labor unions

Feudalism (8th century) Capitalism (18-19th century)

Scientific Approach to Occupational Diseases

$$
\begin{array}{cl}
\text { Lead Poisoning (?) }(400-500 \text { B. G.) } & \text { Hippocrates } \\
\text { Miners' Diseases (1556) } & \text { Agricola }
\end{array}
$$

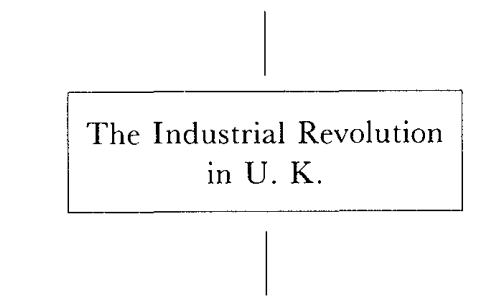

Outbreaks of Occupational Diseases

Ramazzini (18th century)

Protection of Workers in European Countries
Movement to Inaugurate Various Laws and Regulations Relative to Work
Sacrifice of Health (Life)

Emphasis on Tuberculosis Control

Need for Compensation

Importance of Prevention

Health Promotion (Health Education)
In the Last Stage of the Meiji Period (ca. 1900-) Industrialization in Japan (Tragic History of Female Workers, 1925)

From 1905 until World War II Occupational Diseases: Chemical Poisonings \& Pneumoconiosis

Plan for Building up "A Rich Country with a Strong Military Force"

Reconstruction of Industry and Development of Heavy Chemical Industries after World War II

Complicated Working Conditions

New Types of Occupational Diseases and Occupational Cancer

Labour Standard Law

$\mid$

$\leftarrow$ Introduction of Industrial Hygiene

4 Industrial Safety and Health Law (1972)

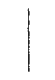

Development of Idea of Prevention among Workers

Forecasting Occupational Medicine

Amendment of Industrial Safety and Health Law (1988)

Fig. 3. Development of occupational health in Japan. 
paid much attention to prevention, but since new occupational diseases such as cervicobrachial disorders, occupational cancer and other occupational diseases as well as environmental pollution were reported, MOL had to enforce other laws. The Industrial Safety and Health Law (ISHL), independent of the LSL, was enacted in 1972. This law was amended in 1988.

The history of occupational health in Japan is very briefly and schematically summarized in Fig. 3. A paper published in 1988 by Reich and Frumkin concludes that "the analysis demonstrates a record for occupational health in Japan considerably more mixed

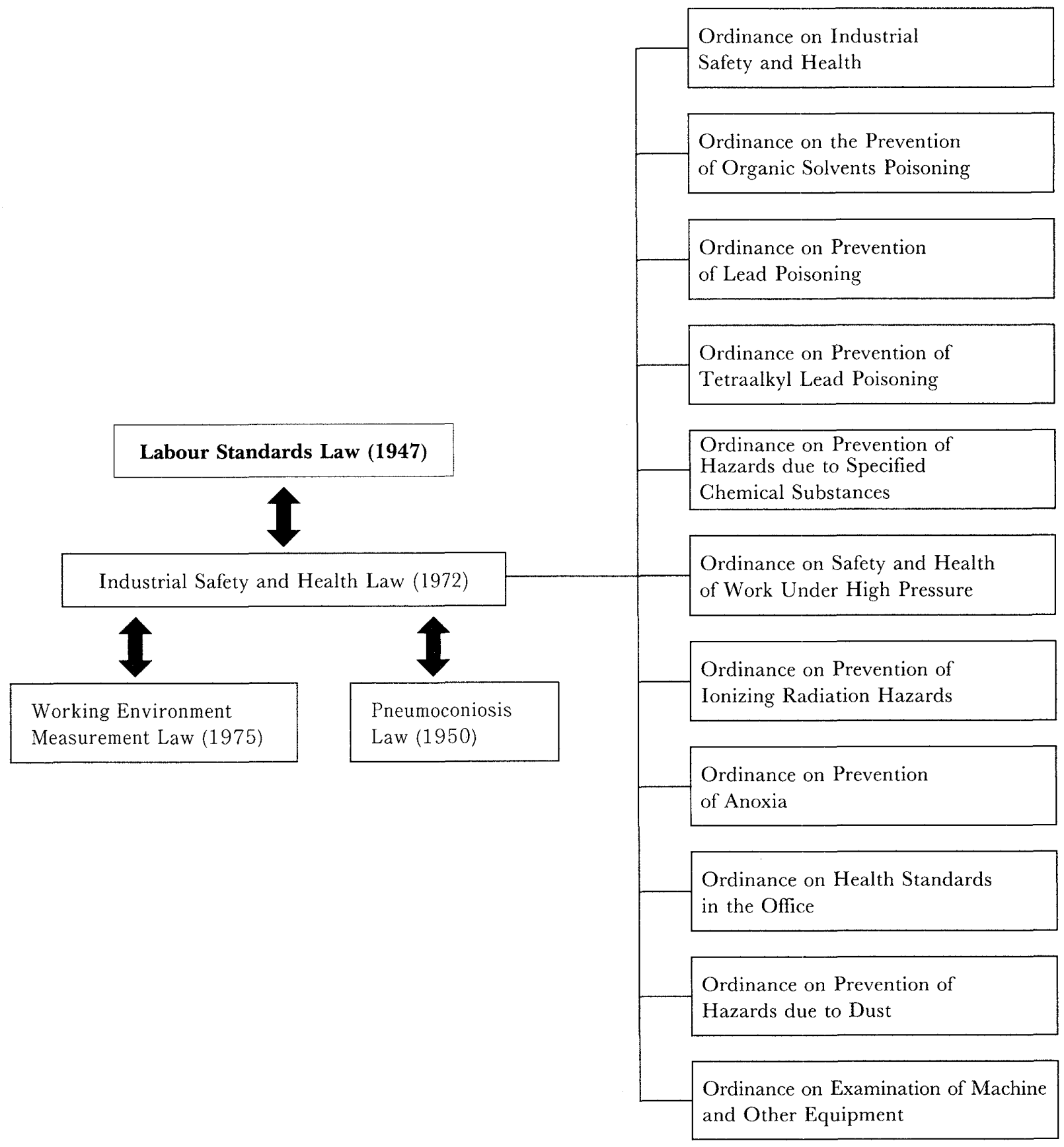

Fig. 4. Passage of Industrial Safety \& Health Law (1972). 
than the conventional view". This statement is partially true for some small firms engaged in hazardous work, but as will be mentioned later, the concept and practice of occupational health are now very advanced, and, in fact, MOL explicitly presents the importance of "health promotion of workers" that goes beyond prevention. The administrative and regulatory system as seen in other Western countries started only after World War II when MOL was established by the Japanese government. However, occupational health services focused on the early detection and treatment of tuberculosis for some years after World War II , as already mentioned. After the ISHL was enacted in 1972, occupational health practice improved greatly. Improvement and amendment of ISHL in 1988 emphasized health promotion. Nevertheless, there is a great disparity in occupational health services between large and small establishments. Figure 4 shows the structure of the amended ISHL in 1972. In 1988 MOL announced a guide on maintenance and promotion of health for the work population.

\section{The Basic Principles of the 1988 Amendment of the ISHL}

The main points of the new ISHL are as follows (Ministry of Labour, 1989b, c):

1) Advancement of health maintenance and promotion measures.

As already mentioned, according to this regulation, MOL started fostering occupational health personnel such as health trainers. I will discuss health personnel later in this paper.

2) Amendment of the Ordinance on Prevention of Ionizing Radiation Hazards.

This ordinance was amended, based on the opinion of the Science and Technology Agency, which responded to the new recommendation by the International Commission on Radiological Protection, i. e., the amendment on exposure limit of radiation dose, the items to be included in, and methods of, health examination and so forth.

\section{3) Improvement of the health examination}

Improvement in this area aims to cope with the increasing number of older workers and the increase in so-called adult diseases such as ischaemic heart diseases, hypertension, diabetes, liver diseases and others. Some may raise the question why should employers be responsible for taking care of such diseases. There exists a "sudden death from overwork" syndrome (Karoshi in Japanese), which some people believe to be the direct result of ischaemic heart disease or stroke. In fact the wives of some victims have been winning compensation by court judgment in recent years. A judge may decide that sudden death by ischaemic heart disease or stroke after continuous overwork is occupationally related. This has been covered extensively in the Japanese press, and on 15 March 1990 in the U. S. A., the New York Times commented on "Karoshi, death from overwork" including the news that the Japanese Labour Ministry is planning to have epidemiological studies performed to 
search for a cause-effect relationship. MOL and a number of companies believe that detailed medical examinations are necessary to prevent these diseases and to promote the health of workers.

The items in the Periodic Health Examination before the Amendment of the ISHL are shown in Table 1. In addition to these items, the new ISHL includes the items shown in Table 2.

4) Increase in the number of designated toxic chemicals which require indicators and work environment measurements.

Thirty organic solvents have been added to the list of those whose concentrations in the work environment must be measured periodically. Indicators for toxic chemicals such as isobutyl alcohol and 17 other organic solvents have been added. The term "indicator" means that the employers must draw the workers' attention by indicating clearly, for example, by labeling "percentage of a toxic chemical in mixed solution" on a bottle or by affixing posters near the source of toxic chemicals, noting the percentage of a toxic chemical in a mixed solution and other relevant information.

5) Evaluation of the result of work environment measures

As shown in Fig. 4, the Working Environment Measurement Law was enacted in 1975

Table 1. The items included in the periodic health examination before amendment of the ISHL

1) history of disease and occupation

2) subjective or objective symptoms

3) height, body weight, visual and hearing capacity

4) chest X-ray

5) measurement of blood pressure and tests for glucose and protein in urine

Table 2. The new ISHL added the following items

Additional items of the periodic health examination (at the time of employment and once a year thereafter)

1) examination for anemia (hemoglobin and red cell count)

2) liver function test (GOT, GPT, gamma-GTP)

3) tests for total cholesterol and triglycerides

4) electrocardiogram

5) hearing test at $1,000 \mathrm{~Hz}$ and $4,000 \mathrm{~Hz}$

Table 3. Occupational health administration in Japan (five basic concepts)

1) well-organized system of occupational health management

2) surveillance and control of work environment

3) improvement of work conditions

4) health evaluation and careful follow-up of health conditions

5) occupational health education 
(Japan Industry Safety \& Health Association, 1983) and the new ISHL obliged employers to improve the work environment based on the results of the measurement of, for example, dust, specific chemicals, lead and organic solvents, and for that purpose the "evaluation criteria for work environment" were put into effect.

6) Promotion of occupational health physicians' activity

The newly amended ISHL requires more active work by occupational health physicians including maintenance of the work environment, control of the conditions of work load and so forth. In order to improve occupational health practices in small establishments, "model areas" were designated by county or city medical associations in 1989.

In these model areas, counseling on occupational health is provided by local part-time occupational health physicians. The training and education of part-time occupational

\begin{tabular}{|c|c|c|}
\hline \multirow{6}{*}{$\begin{array}{l}\text { Occupational Health } \\
\text { Physician } \\
\text { Health Evaluation } \\
\end{array}$} & \multirow[b]{2}{*}{ Health Guidance } & \multirow{5}{*}{$\begin{array}{l}\text { *Medical examination by } \\
\text { interview } \\
\text { i. e. }{ }^{*} \text { Medical examination } \\
{ }^{*} \text { Check up } \\
{ }^{*} \text { Evaluation } \\
{ }^{*} \text { Preparation of guidance sheet }\end{array}$} \\
\hline & & \\
\hline & \multirow{2}{*}{\begin{tabular}{|l} 
Exercise Program \\
Mental Health Care \\
\end{tabular}} & \\
\hline & & \\
\hline & Nutrition Guidance & \\
\hline & Health Life Guidance & (For all workers) \\
\hline $\begin{array}{l}\text { Health Care Trainer } \\
\text { Health Care Leader }\end{array}$ & & Exercise Program, etc. \\
\hline \multirow[t]{2}{*}{$\begin{array}{l}\text { Exercise Program } \\
\text { Practical Exercise }\end{array}$} & & $\begin{array}{l}\text { *Prepare exercise program } \\
\text { i. e. }{ }^{*} \text { Guide practical exercise }\end{array}$ \\
\hline & & (For workers who require health guidance) \\
\hline Mental Health Care Counselor & & Mental Health Care \\
\hline Mental Health Care & & $\begin{array}{l}{ }^{*} \text { Assist worker to } \\
\text { become aware of stress } \\
\text { i. e. }{ }^{*} \text { Guide relaxation } \\
{ }^{*} \text { Counseling }\end{array}$ \\
\hline
\end{tabular}

(For workers who require health guidance)

\begin{tabular}{|l|l|l|}
\hline $\begin{array}{l}\text { Nutrition Guidance Gounselor } \\
\text { (Dietitian) }\end{array}$ & \multicolumn{1}{c|}{ Nutrition Guidance } \\
\hline $\begin{array}{l}\text { Nutrition Guidance } \\
\text { (For all workers) }\end{array}$ \\
\hline
\end{tabular}

\begin{tabular}{|l|l|l|}
\hline \multicolumn{1}{|l|}{ Public Health Nurse \& Nurse } & $\begin{array}{c}\text { Health Life Guidance } \\
\text { Health Life Guidance }\end{array}$ & $\begin{array}{r}\text { * Guide proper living } \\
\text { including sleeping, } \\
\text { smoking, drinking, etc. } \\
\text { *Health coordination }\end{array}$ \\
\hline
\end{tabular}

Fig. 5. A flowchart of total health promotion in factories. 
Table 4. Total health plan

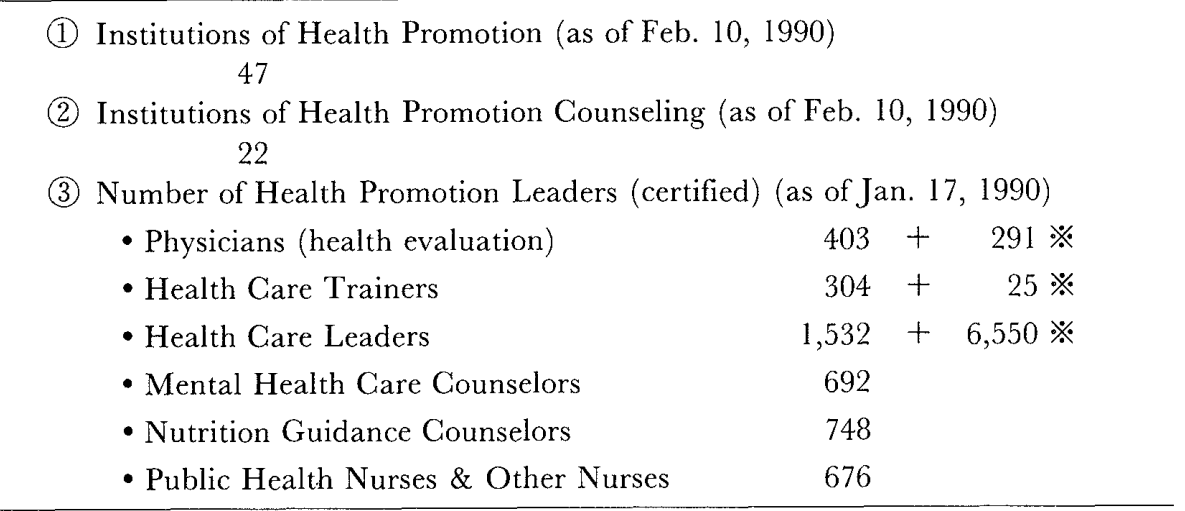

※ Number of HPL who completed SHP program (JISHA, 1990)

Table 5. Periodic medical examinations conducted at companies of varying size

\begin{tabular}{cc}
\hline Number of employees & $\%$ \\
\hline $1,000-$ & 100 \\
$50-999$ & $95.5-99.4$ \\
$30-49$ & 91.0 \\
$10-29$ & 73.3 \\
\hline Average & $79.2(\%)$ \\
\hline & (MOL, 1989)
\end{tabular}

health physicians has also been strengthened in terms of quality and activity.

In summarizing occupational health administration in Japan, the five basic principles shown in Table 3 have been adopted by MOL.

Among these principles MOL emphasizes measurement and promotion of both physical and mental health (total health plan: THP). MOL has suggested a flow chart showing teamwork by occupational health personnel. In organizing a team for implementing the purpose, as shown in Fig. 5, MOL strongly recommends that employers with 50 or more employees consult a team of occupational health workers including a physician, health care trainer, health care leader, mental health care counselor, nutrition guidance counselor, and public health nurses or nurses who work in institutions designated by MOL. As the figure shows, occupational physicians play an important role in the THP.

As shown in Table 4, there are 47 institutions certified by MOL to serve this total health plan. There are 22 institutions which train these occupational health workers (Japan Industrial Safety \& Health Association, 1990). According to a survey carried out in February 1990, there are about 700 physicians who are registered as qualified to measure the health level of workers. About 330 health care trainers, 8,000 health care leaders, 700 mental health care counselors, 750 nutrition guidance counselors and about 700 public health nurses and other nurses are registered. In the table, the asterisks show the numbers of those who completed the training specified by MOL. The idea of a total health 
Table 6. Medical examinations for adult diseases

\begin{tabular}{cc}
\multicolumn{2}{c}{ conducted at companies of varying size } \\
\hline Number of employees & $\%$ \\
\hline $5,000-$ & 100 \\
$300-4,999$ & $90.6-98.0$ \\
$50-299$ & $61.8-74.4$ \\
$30-49$ & 52.7 \\
$10-29$ & 41.8 \\
\hline Average & 47.1 \\
\hline
\end{tabular}

Table 7. Mental health care given at companies of varying size

\begin{tabular}{cc}
\hline Number of employees & $\%$ \\
\hline $5,000-$ & 94.9 \\
$300-4,999$ & $65.1-79.5$ \\
$50-299$ & $41.0-46.9$ \\
$10-49$ & $26.9-32.5$ \\
\hline Average & 30.3 \\
\hline
\end{tabular}

plan is very good, but this is still at the beginning stage and only large establishments can afford such services. In fact, as shown in Table 5, 100\% of establishments with more than 1,000 employees performed periodic health examinations, but the figure for small firms of fewer than 30 employees is only 73\% (Ministry of Labour, 1989d). Table 6 shows the percentage of companies which performed medical examinations for adult conditions such as heart disease and hypertension, diabetes or liver disease, etc. by size of establishment. An average of only $47 \%$ of the establishments actually performed these examinations (Ministry of Labour, 1989d). As shown in Table 7, mental health care was provided in only $30 \%$ of the establishments (Ministry of Labour, 1989d), which shows that it is very difficult to encourage small businesses to be very active in occupational health.

\section{Weaknesses of Occupational Health in Japan}

What I have said so far may give you a favorable image of occupational health practices in Japan, but in reality there are numerous weak points and many disadvantages and limitations.

First of all, while for the most part large enterprises provide well-organized occupational health staffing and financing, the standing of the occupational health physician is, in general, not very high. It is not uncommon for occupational health physicians to hold positions under the chief or director of the labor office or the personnel section, which 
means that it is difficult for the opinion of the occupational health physician to reach top management. Nor is the social status of the occupational health physician as high as that of other medical specialists. The need for, or usefulness of, the occupational health physician is not always clear to top level managers because they are not always aware of what occupational health physicians are expected to do on the job. Some members of top management still believe that the physicians are concerned mainly with health examinations of workers or treatment of patients. One reason for this is that there is no certificate or license specifically for occupational health physicians. Any licensed physician is eligible to be appointed as a full-time occupational health physician. Although the Japan Medical Association periodically holds various training courses on occupational health for part-time occupational health physicians at the national and local level, this is not sufficient to provide the kind of occupational health services that can be expected of fully qualified physicians. The University of Occupational and Environmental Health, Japan, was established 12 years ago to train and foster occupational health personnel. At our medical school, a course on occupational health starts from the 4th year, followed by a three-month course immediately after graduation. Approximately 100 of 540 graduates are currently engaged in occupational health practice in industry, academia (mostly at our university), and government. Since the establishment of our university, I have been working to persuade MOL to establish national certificaiton for qualified occupational health physicians and public health nurses. Otherwise, there is no reason for students to study at the school of medicine or the other schools of our particular university. I hope that a system of certification for occupational health personnel will be authorized in Japan as quickly as possible.

The second weakness is that small businesses, especially those with fewer than $50 \mathrm{em}$ ployees, provide very poor services. Although MOL encourages the owners of these establishments to promote occupational health services by providing financial support, the employers are, in general, more concerned with productivity.

The third weakness concerns the periodic medical examination as well as specific medical examinations for those workers possibly exposed to toxic elements, chemicals or physical agents. There are three major problems. Since the periodic medical examination and other examinations have added many items including laboratory tests to the new ISHL, the cost of examinations has increased, raising the financial burden of employers, especially those of small companies. A second problem is that some medical scientists, myself included, doubt the necessity of chest $\mathrm{x}$-rays in routine medical examination. However, MOL cannot exclude chest x-rays from the periodic examination because of the Law for Prevention of Tuberculosis which continues to be enforced by the Ministry of Health and Welfare. Although tuberculosis is no longer the problem it once was in Japan, it is very difficult to abolish existing laws. The third problem involves cost-benefit management. There is question as to whether this type of expensive medical examination is really useful for maintaining the health of workers and detecting the early stages of a disease. In fact, those individuals with, for example, heart disease, hypertension or di- 
abetes usually know that they are suffering from such diseases and are already under a doctor's care.

These are just a few of the major problems we face at this time in Japan concerning the occupational health system.

\section{Conclusion}

I hope this short paper has given you a rough overview of the historical development of occupational health in Japan. Industrialization in Japan started later than in the European countries. Indeed it was Europe and particularly the United Kingdom, which introduced modern industry to us before World War II. Then, after World War II the pace of industrialization became so rapid that occupational health service in industry could not keep up. After the enactment of the Industrial Safety and Health Law in 1972, occupational health service reached a level equal to that of other industrialized countries. Health maintenance and promotion, both physical and mental, has become a top priority of MOL from 1988. However, there remain numerous obstacles to providing better occupational health service, and, unfortunately, it may take a long time to solve all the existing problems.

\section{References}

Hoover, H. C. \& Hoover, L. H. (Translation) (1950): De Re Metallica (Latin edition of 1556 by Agricola, G.), Dover Publications, New York. 638 pp.

Japan Industrial Safety and Health Association (ed.) (1983): Industrial Safety and Health Law and Related Legislation of Japan. JISHA, Tokyo. 921 pp.

Japan Industrial Safety and Health Association (1990): Personal communications.

Kubota, J. (1979): Atlas of Occupational Diseases. Japan Industrial Safety and Health Association, Tokyo. 265 pp. (in Japanese)

Ministry of Labour (1989a): White Paper on Labour. The Japan Institute of Labour, Tokyo. 292 pp. (in Japanese)

Ministry of Labour, Labour Standards Bureau, Industrial Health Division (1989b): Total health promotion for workers (Part 1). Occup. Health J., 12(1): 4-10. (in Japanese)

Ministry of Labour, Labour Standards Bureau, Industrial Health Division (1989c): Total health promotion for workers (Part 2). Occup. Health J., 12(3): 3-10. (in Japanese)

Ministry of Labour, Minister's Secretariat, Policy Planning and Research Department (1989d): A Report of Workers' Health Condition (1987). Ministry of Labour, Minister's Secretariat, Policy Planning and Research Department, Tokyo. 324 pp. (in Japanese)

Miura, T. (1976): Introduction to the history of occupational health (Part 5). J. Science of Labour, 52: 397-405. (in Japanese with English summary)

Miura, T. (1978): History of Occupational Health in Japan. Vol. 1. Institute for Science of Labour, Kawasaki. 281 pp. (in Japanese)

Miura, T. (1980a): History of Occupational Health in Japan. Vol. 2. Institute for Science of Labour, Kawasaki. 351 pp. (in Japanese)

Miura, T. (1980b): History of Occupational Health in Japan. Vol. 3. Institute for Science of Labour, Kawasaki. 305 pp. (in Japanese) 
Miura, T. (1981): History of Occupational Health in Japan. Vol. 4. Institute for Science of Labour, Kawasaki. 476 pp. (in Japanese)

Organization for Economic Co-operation and Development (OECD) (1988): The Future of Social Protection. OECD, Paris. 64 pp.

Reich, M. R. \& Frumkin, H. (1988): An overview of Japanese occupational health. Am. J. Public Health, 78: $809-816$.

Tsuchiya, K. (1990): A brief overview of occupational health in Japan in recent years. J. Occup. Med., Singapore, 2(1): 24-31.

\section{日本における労衝衛生の発展}

土 屋 健三郎

産業医科大学 学長

要旨： 本論文は, 1990 年, 英国の王室医師学会産業医学部会による招聘講演 (Lucas Lecture) と して発表したものである.我が国の労衝衛生について8世紀まで遡り，その間の変遷につ いて総括したものである．また，労働基準法およびその施行による成果や問題点について 記載する. 1988 年の労働安全衛生規則の改正を詳述し, 問題点として大企業と中小企業 間における産業保健サービスの大きな格差を述べる，最後に，1978 年に産業医科大学が 産業医学 (産業保健科学) の進展と産業保健従事者, 特に, 产業医の養成を目的として設 立されたことを紹介する，そして，専属産業医の資質についての制度を至急整備する必要 性があることを指摘する。

J. UOEH (産業医大誌)，13 (3): 191-205 (1991) 